\title{
A Qualitative Study Exploring Neurodiversity Conference Themes, Representations, and Evidence-Based Justifications for the Explicit Inclusion and Valuing of $O C D$
}

Damian Mellifont, The University of Sydney, Australia

\begin{abstract}
The inclusivity of neurodiversity conferences is a new field of research. Utilising Obsessive Compulsive Disorder (OCD) as an example, this study aims to critically investigate issues of inclusivity in the flyers advertising these conferences. This exploratory research is informed by 22 conference flyers and 14 scholarly articles retrieved from respective internet and Google Scholar enquiries. These articles offered evidence-based justifications for a greater inclusion of OCD-focused content in neurodiversity conferences. The study cautions that the lack of explicit inclusion of OCD as a topic among conferences can be harmful to persons who identify with this particular type of neurodivergence. This study offers a sound base from which future research focusing upon other forms of neurodivergence and issues of neurodiversity conference inclusivity and intersectionality can develop.
\end{abstract}

Keywords: conferences; inclusion; neurodiversity; Obsessive-Compulsive-Disorder; policy

Publication Type: special section publication

\section{Introduction}

$\mathrm{B}$ illions are expended on multiple-day conferences each year (Rog \& Wolffe, 1994 as cited in Neves et al., 2012). While representing a large investment, the benefits that these conferences can offer attendees are notable. These benefits include keeping up to date in one's field, gaining fresh ideas, and establishing program and interest alliances (Ferman, 2002; Hickson, 2006). Around the world, contemporary disability conferences are presenting studies along with "reflective work" that is centred upon socially created disabling obstacles (Callus, 2017, p.1661). In addition to learning and networking prospects, conferences also present opportunities to travel and relax (Ngamsom \& Beck, 2000). At their finest, conferences permit academics to converge in a cooperative community that is devoted to distributing, generating, and absorbing knowledge (Manning, 2018).

While offering many benefits, conferences are, however, not immune from challenges. The complexity of issues that are discussed at large conferences can result in organisers struggling to set clear conference objectives (Mathieson, 2009; Tepper \& Hinton, 2003 as cited in Neves et al., 2012). Conferences can also struggle to be more inclusive. Resources, space, and time, together with psychological and physical outlays, can discourage people from joining conferences (Ngamsom \& Beck, 2000). De Picker (2019) recognises that the representation of disability 
activism within scholarly conferences will continue to be constrained where attendance is availed only to those who have capacity to pay. Crucially, Coe et al. (2019) caution that societies and organisations who fail to provide "diverse and inclusive conferences" should be held to account (p. 590). Moreover, according to Gordon and Gledhill (2018), "the mantra of 'nothing about us without us' applies equally to conferences as it does to anything else concerning mental healthwhat's more, that must extend to all aspects of the conference in order to be meaningfulorganising committees, key-note and concurrent session presentations, posters, attendees, panellists" (p. 110).

Before broaching the topic of neurodiversity conferences, it is appropriate to consider some of the complexities that are inherent to the term. Neurodiversity should not be presumed to be fixed, understood, or universally accepted. Put simply, neurodiversity can take on different meanings for different individuals (Chapman, 2020). Steve Silberman's (2017) publication Neurotribes supports the understanding that all brains are different, and that autism is a sample of such diversity (Silberman, 2017 as cited in Baron-Cohen, 2017). In the U.K., efforts have been made to develop a community that is wider than autism (Arnold, 2017). Hence, moving beyond its original use by Judy Singer (an Australian social scientist who has lived experience with autism) in her description of a "self-advocacy movement," neurodiversity has grown to encompass a range of conditions including Autistic Spectrum Disorder, Dyslexia, Tourette Syndrome, Dyspraxia, and Attention Deficit Hyperactivity Disorder (ADHD), among others (Dalton, 2013; Baron-Cohen, 2017). While the 1960s saw Canada recording expressions of Mad Pride in reaction to psychiatric institutionalisation, the neurodiversity movement (NDM) would rally in the latter part of the twentieth century through the use of internet sites that were primarily based in Europe and the U.S. (Dyck, 2020).

Typical of social justice causes, the NDM is not exempt from criticisms (den Houting, 2019). A suggestion is put forward that the movement has been controlled by persons with Asperger Syndrome and other types of "high-functioning autism" (Ortega, 2009 as cited in Russell, 2020). Some argue that "functioning labels" are damaging (Chapman, 2021). Individuals who are seen as high functioning can find it extremely challenging to obtain support, while the low functioning label can overlook abilities (Williams, 2019). Research from Alvares et al. (2020) support movement away from binary descriptors (i.e., low/high functioning) and towards more appreciation of the variance in function that exists throughout the autism spectrum.

Kapp et al. (2013) also note that the NDM has generated controversy in its quest for quality of living and social change over cure. Rothstein (2012) reports that some public figures, "including many parents," focus on the challenges that can accompany mental conditions (p. 100). Further, Russell (2020) advises of the notable benefits to be realised from medical diagnosis including those of attaining access to services, gaining an understanding of lived experiences, and obtaining an assembly point for political activity. In contrast, the social model sees disability as a consequence of challenging physical and social settings, rather than resulting from the condition itself (Berridge \& Martinson, 2018). Friction thus continues between two competing ideologies (i.e., the social model that the movement openly supports and the medical model that it tends to oppose). Some people might thus reject neurodiversity for its failure to treat mental illness, while others might reject being labelled with medical conditions along with any suggestion that they need medical treatment. Still, there are individuals who identify as neurodiverse that find both models to be useful. In this way, neurodiversity advocates exist who are accepting of the medical model (McWade et al., 2015).

The International Journal of Information, Diversity, \& Inclusion, 5(2), 2021

ISSN 2574-3430, jps.library.utoronto.ca/index.php/ijidi/index

DOI: $10.33137 /$ ijidi.v5i2.35067 
According to Parsons et al. (2017), "ableism is most often used to describe the negative treatments of individuals with disability" (p.207). Ableism is steeped in negative assumptions concerning disability (Hehir, 2002 as cited in Storey, 2007). Clare (2004) cautions about ableism in terms of its potential to segregate and deny opportunities to achieve. Conversely, in the NDM, neurological variances are seen as natural (Milton \& Moon, 2012 as cited in McWade et al., 2015). Neurodiversity advocates recognise the positive attributes of brains that operate differently (Rothstein, 2012).

Debate too persists around neurodiversity-related language. Strand (2017, n.p.) uses the term neurodivergent to refer to persons who identify as "other than neurotypical." This latter term depicts "the majority brain" (Murdock, 2020, p.14). Neurodiversity in turn emphasises that variances in brain function are seen as a natural part of human variation (Clouder et al., 2020). The lexicon of the NDM, however, is not beyond contestation. No consensus has been reached on the appropriateness of expressions such as neurodifferent, neurodivergent, and neurodiverse (Doyle, 2020). Russell (2020) argues that the boundary determining who is included in the neurodivergent group is presently ill-defined. Further, as far as the author is aware, a popularly recognised, progressive alternative for the medical term of Obsessive-Compulsive-Disorder (OCD) remains unavailable. The term "OCD" has thus been used throughout in this paper. The author also makes references to the medical model in the context of its capacity to allow for the formal diagnosis of various forms of neurodivergence and subsequent access to accommodations on an individualised basis.

Recognising the complex and dynamic nature of the NDM, it is appropriate to investigate the inclusiveness or otherwise of conferences that are promoted under its banner. Hence, in addition to investigating the topics that are promoted in these conference flyers, this study shall explore the types of neurodivergence that are explicitly mentioned. Of particular interest to this exploration is OCD. According to Sane Australia (2018), "people living with OCD are troubled by recurring unwanted thoughts, images, or impulses, as well as obsessions and repetitive rituals." It is appropriate at this point, however, to also recognise the possible strengths that might be attributed to this particular form of neurodivergence. The literature has raised potential for OCD and anxiety more broadly to respectively assist in advancing work quality and quantity by motivating one to operate meticulously and diligently (Hayes-Skelton et al., 2013; Johnson, 2014 as cited by Mellifont, 2019). Mellifont et al. (2019) also report on the potential of anxiety to support the completion of PhD level study.

Appreciating that one form of neurodivergence is not more important than another, the author also notes a strong representation of OCD among populations. Such representation is exemplified in the Anxiety and Depression Association of America (2020) reporting of 2.2 million American adults who are living with OCD. As many persons have lived experience with OCD, it is appropriate that topics of interest for these individuals do not tend to be overlooked in neurodiversity conferences. While the Annual OCD Conference is dedicated to this particular type of neurodivergence (International OCD Foundation, 2019), to the author's knowledge, there is a scarcity of information available about the broader inclusion of OCD in neurodiversity conference promotional materials. Utilising $O C D$ as an example, this study aims to critically investigate issues of inclusivity for these conferences.

\section{Method}

In order to locate conference flyers relevant to the first aim of this study, an internet search was

The International Journal of Information, Diversity, \& Inclusion, 5(2), 2021

ISSN 2574-3430, jps. library.utoronto.ca/index.php/ijidi/index

DOI: $10.33137 /$ ijidi.v5i2.35067 
implemented using the term, "neurodiversity conference flyers." A supplementary Google enquiry using the broader search term of "neurodiversity" AND "conference" was then conducted. Conference flyers with a neurodiversity focus (i.e., the term neurodiversity is specifically mentioned in the conference title) and with a conference date between 2014 and 2021 were considered to be relevant. Given the preliminary nature of this study, searches were purposefully confined to the English language. Furthermore, events were restricted to conferences (i.e., large gatherings where professionals share and discuss viewpoints on certain topics) as opposed to symposiums (i.e., smaller scientific gatherings where experts present about a particular topic of interest) (van de Venter, 2019). It is therefore recognised that neurodiversity events do exist beyond those included in this study and that these events are conducted in different languages, for example, "conferencia neurodiversidades" and formats, such as, "symposiums."

Thematic analysis of pertinent flyers involved: a) reading the texts; b) identifying conference themes, their coding rules, and exemplary quotes, and c) recording this information in tabular form. Following on, descriptive statistics were applied to calculate the proportional representations of these themes among conference flyers. Neurodivergence types and supporting quotes were captured and recorded and descriptive statistics were again used to determine their proportional representations across the promotional materials.

Informing evidence-based justifications for the greater inclusion of OCD focused content in neurodiversity conferences, a Google Scholar search was carried out applying the search term, "neurodiversity" AND "obsessive compulsive disorder" AND "inclusion." Selection criteria consisted of: document type = journal article; article informs about the potential inclusion of OCD-related topics in neurodiversity conferences; publication date = post 2015; and article is retrievable. The publication date range was purposively selected so as to support a contemporary sample of scholarly articles of sufficient volume to support the study aim. Thematic analysis was applied to the relevant articles. As directed by Braun and Clarke (2006), this analysis involved: a) becoming conversant with the data; b) recognising themes; c) rereading the themes; and d) reporting the results. Evidence-based themes supporting the explicit inclusion of OCD within neurodiversity conferences, their coding instructions, and supporting quotes were documented in tabular form as well.

\section{Results}

The Google search for conference flyers produced 149 possibly relevant flyers with 11 of these being accepted after applying the inclusion criterion of the term neurodiversity as promoted within the conference title. The supplementary internet search produced an additional 11 flyers from the first five pages of results, bringing the total number of neurodiversity conference flyers to 22. Conference titles together with their respective locations and dates are provided in the following section (Conferences). Thematic analysis of these flyers produced themes of employment, education, social, advocacy, health, and policy. Themes, their coding instructions, and exemplary texts are provided in Table 1. Table 2 depicts the proportional representations of these themes across the conference flyers.

\section{Conferences (Titles, locations, and dates)}

1. 2021 AMF Power of Neurodiversity Conference: Cultivating Success in the Classroom \& Beyond! (U.S., St. Louis, Missouri; 25 \& 26 March 2021).

The International Journal of Information, Diversity, \& Inclusion, 5(2), 2021

ISSN 2574-3430, jps. library.utoronto.ca/index.php/ijidi/index

DOI: $10.33137 /$ ijidi.v5i2.35067 
2. 2019 National neurodiversity and mental health conference. (England; Liverpool, 4 Oct 2019).

3. St. Louis neurodiversity conference. (U.S., St Louis, Missouri, 24 \& 25 Apr, 2019).

4. Empowering neurodiversity - Developing services for neurodiverse young people with neurodiverse young people. (U.S., Phoenix, 51-16 Sep 2016).

5. Neurodiversity in the workplace national conference: A collaborative conference event. (U.S., Maryland, 7 \& 8 Nov 2019).

6. Neurodiversity: How prepared are you to train students with hidden disabilities? (England, Bristol; 4 Sep 2018).

7. Solutions for learning conference: Neurodiversity rocks! (Canada, Ontario; 21 Mar 2014).

8. Thinking differently about god: Neurodiversity, faith \& church. (England, London; 12 Oct 2019).

9. 2nd annual CUNY neurodiversity conference. (U.S., New York; 11 \& 12 Mar 2019).

10. Supporting Neurodiversity. (England, York; 5 Oct 2017).

11. Neurodiversity leaders 2016 in San Francisco. (Unites States, San Francisco; 8 Oct 2016).

12. Nurturing Invisible Superpowers: A Conference on Neurodiversity. (Canada, British Columbia; 27 \& 28 Apr 2020).

13. Neurodiversity and the Criminal Justice System. (Ireland, Dublin, Leinster; 1 Nov 2019).

14. The Neurodiversity Employment Conference. (England, Welwyn Garden City; Hertfordshire; 4 October 2018).

15. Diverse Minds: The Neurodiversity Conference. (England, London; 1 March 2018).

16. Online Conference: Neurodiversity and the Creative Arts. (streamed from England, London; 16-17 Nov 2020).

17. Neurodiversity in the High-Tech Workforce: Celebrating abilities in a culture of disability. (U.S.; 7 June 2016).

18. 3rd Annual CUNY Neurodiversity Conference. (U.S., New York; 12 \& 13 Mar 2020).

19. Neurodiversity Matters Conference. (U.S., streamed from Rhode Island; 29 \& 30 Apr 2020).

20. Neurodiversity at Work: Thinking Differently \& Supporting Unique Talents. (England, streamed from London; 14 Jan 2021).

21. Neurodiversity: It takes all kinds of different minds. (England, streamed from London; 10-12 Nov 2020).

The International Journal of Information, Diversity, \& Inclusion, 5(2), 2021

ISSN 2574-3430, jps.library.utoronto.ca/index.php/ijidi/index

DOI: $\underline{10.33137 / \text { ijidi.v5i2.35067 }}$ 
22. Neurodiversity and Workplace Inclusivity. (U.S., Washington, D.C. virtual conference); 16 Sep 2020).

Table 1. Neurodiversity conference flyer themes

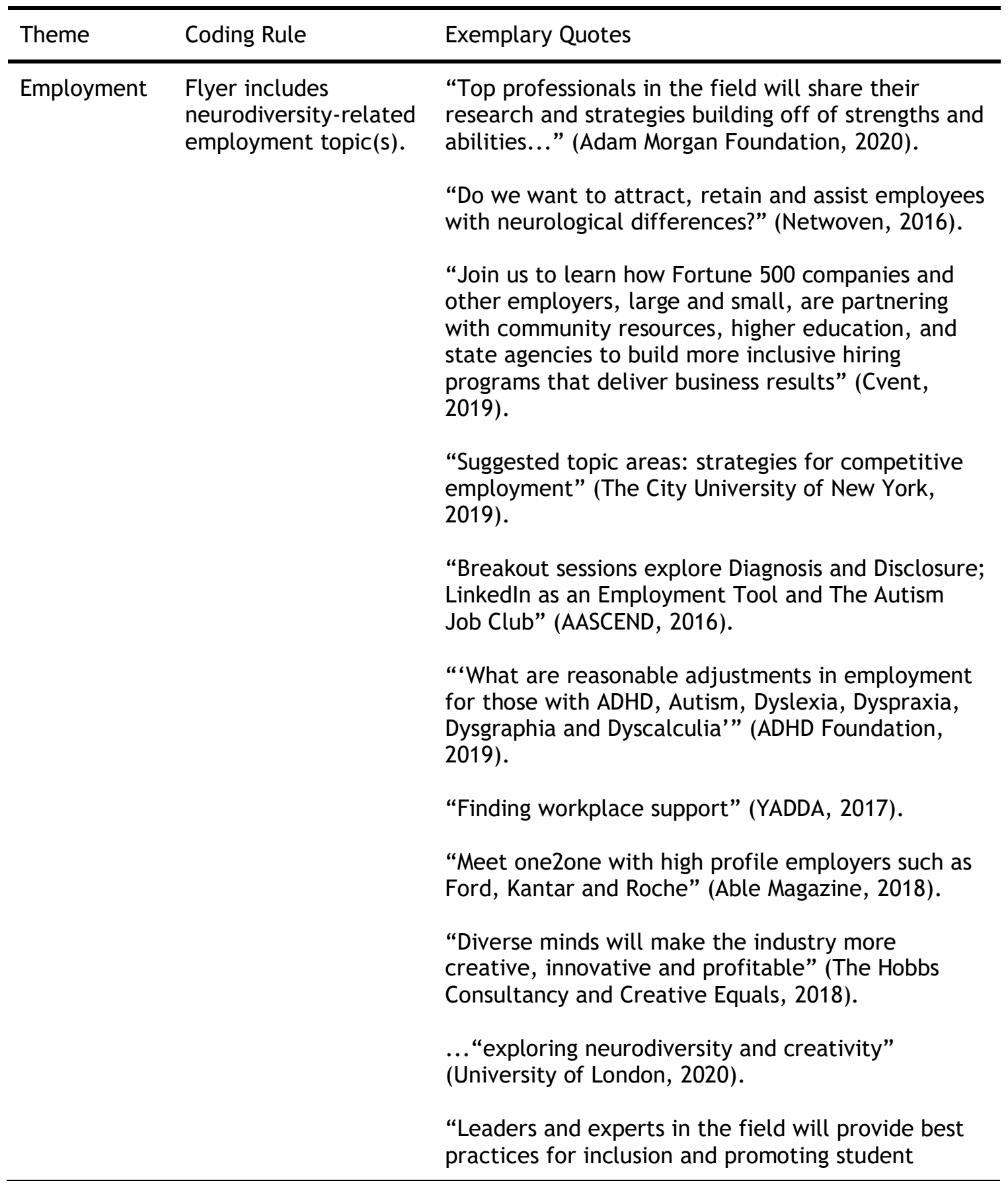

The International Journal of Information, Diversity, \& Inclusion, 5(2), 2021

ISSN 2574-3430, jps.library.utoronto.ca/index.php/ijidi/index

DOI: $10.33137 /$ ijidi.v5i2.35067 


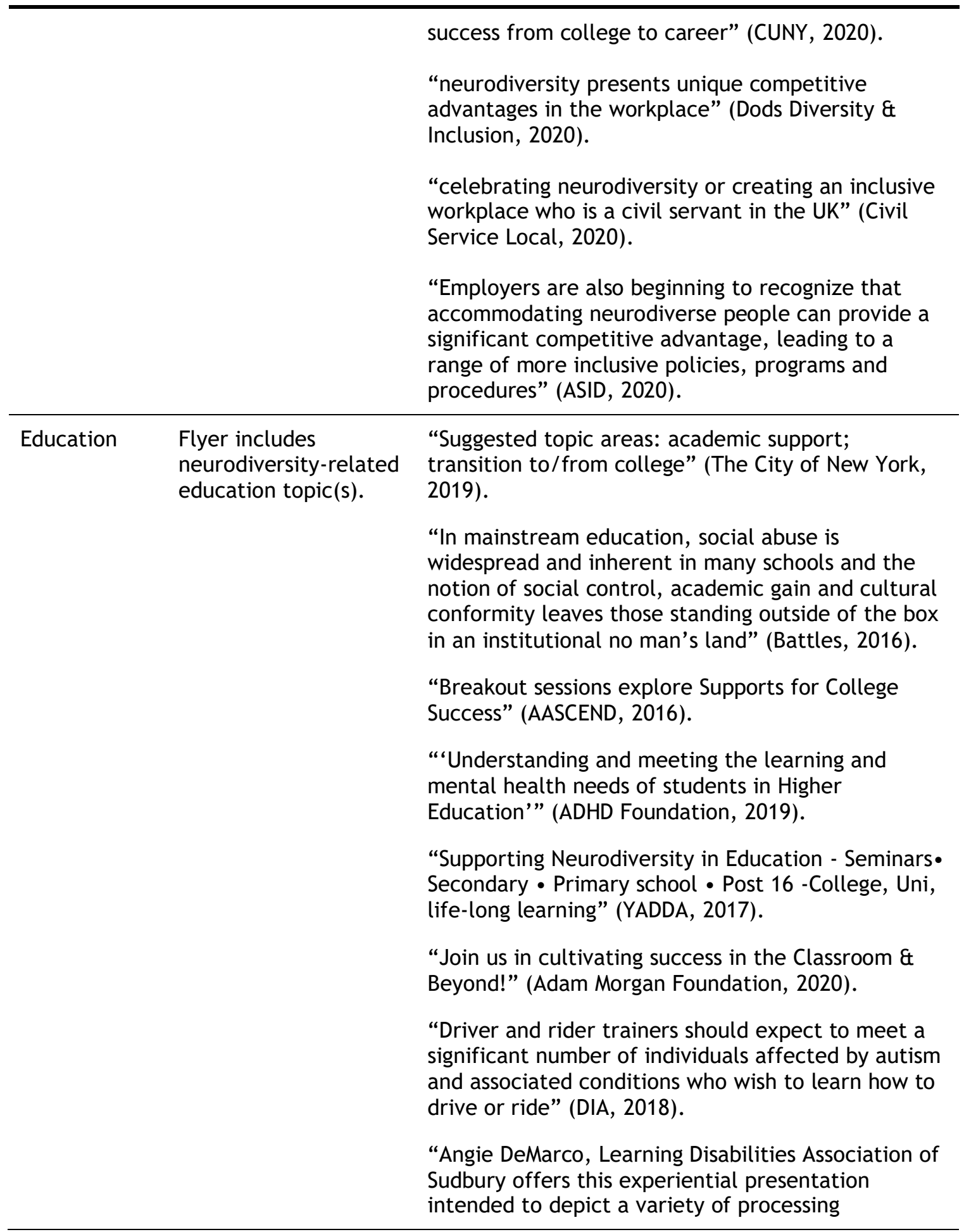

The International Journal of Information, Diversity, \& Inclusion, 5(2), 2021

ISSN 2574-3430, jps.library.utoronto.ca/index.php/ijidi/index

DOI: $\underline{10.33137 / \text { ijidi.v5i2.35067 }}$ 
differences faced by students when they are academically challenged in the structured learning environment known as 'school'” (LDAH, 2014).

"The Conference seeks to promote a shared understanding of neurodiversity: a concept where neurological (brain development) differences are recognized and respected as variations rather than disorders, like any other human differences" (Insight Support Services, 2020).

"The goal is to provide attendees with an up to date understanding of the impact of neurodevelopmental conditions on offending behaviours and to highlight practical strategies that have been shown to be effective in working with individuals who are neurodiverse within the criminal justice system" (Association for Criminal Justice Research and Development (ACJRD, 2019).

\section{Social}

"This is a one of a kind conference, bringing a fresh perspective and hope for true inclusion in our society" (Adam Morgan Foundation, 2020).

"Suggested topic areas: social inclusion and recreation; independent living" (The City of New York, 2019).

"Some of the other sessions at the conference will be: guardianship alternatives; Circling up: parenting support groups; guardianship alternatives" (American Institute for Learning and Human Development, 2019).

"Breakout sessions explore Dating on the Spectrum" (AASCEND, 2016).

"ADHD is a family affair - how ADHD impacts on the family"” (ADHD Foundation, 2019).

"empower our neurodiverse community in achieving equal opportunity and full participation in society" (Spectrum Theatre Ensemble, 2020).

"In bringing both worlds together we have an opportunity to empower those who are wired differently with those who currently set the rules" 
(Battles, 2016).

"in this panel AASCEND Co-Chair Greg Yates moderates a convocation of leading autism advocacy organizations, including Autism Society of America, Autism Global Initiative, Different Brains, GRASP and others to hear the state of autism advocacy and where we share common ground" (AASCEND, 2016).

"sharing experience of discovery, discrimination and discernment" (St. Martin in the fields, 2019).

\begin{tabular}{|c|c|c|}
\hline Health & $\begin{array}{l}\text { Flyer includes } \\
\text { neurodiversity-related } \\
\text { health topic(s). }\end{array}$ & $\begin{array}{l}\text { "Some of the other sessions at the conference wi } \\
\text { be: nutrition and autism; benefits of functional } \\
\text { movement in crossfit \& autism; Positive Boost of } \\
\text { Animal Therapy" (American Institute for Learning } \\
\text { and Human Development, 2019). }\end{array}$ \\
\hline & & $\begin{array}{l}\text { “'An opportunity for teachers to trial QB Check } \\
\text { ADHD Screening Tool for Schools”” (ADHD } \\
\text { Foundation, 2019). }\end{array}$ \\
\hline
\end{tabular}

Policy

Flyer includes policyrelated neurodiversity

"“A national Strategy for Autism"” (ADHD topic(s). Foundation, 2019).

Keynote speech - YADDA-DSSY "Bringing the National agenda to the local level" (YADDA, 2017).

Table 2. Theme proportional representations in conference flyers

\begin{tabular}{ll}
\hline Theme & \% of conference flyers \\
\hline Employment & 63.6 \\
Education & 45.5 \\
Social & 27.3 \\
Advocacy & 13.6 \\
Health & 9.1 \\
Policy & 9.1 \\
\hline
\end{tabular}

The International Journal of Information, Diversity, \& Inclusion, 5(2), 2021 
Table 3 reports on the types of neurodivergence as availed within conference flyers along with supporting quotes. These "types" include autism, ADHD, dyspraxia, dyscalculia, dyslexia, Tourette Syndrome, specific language impairment, intellectual disability, dysgraphia, neurodiversity (catchall reference), and others. Table 4 provides the proportional representations of these forms of neurodivergence across the conference flyers.

Table 3. Representations in conference flyers by neurodivergence type

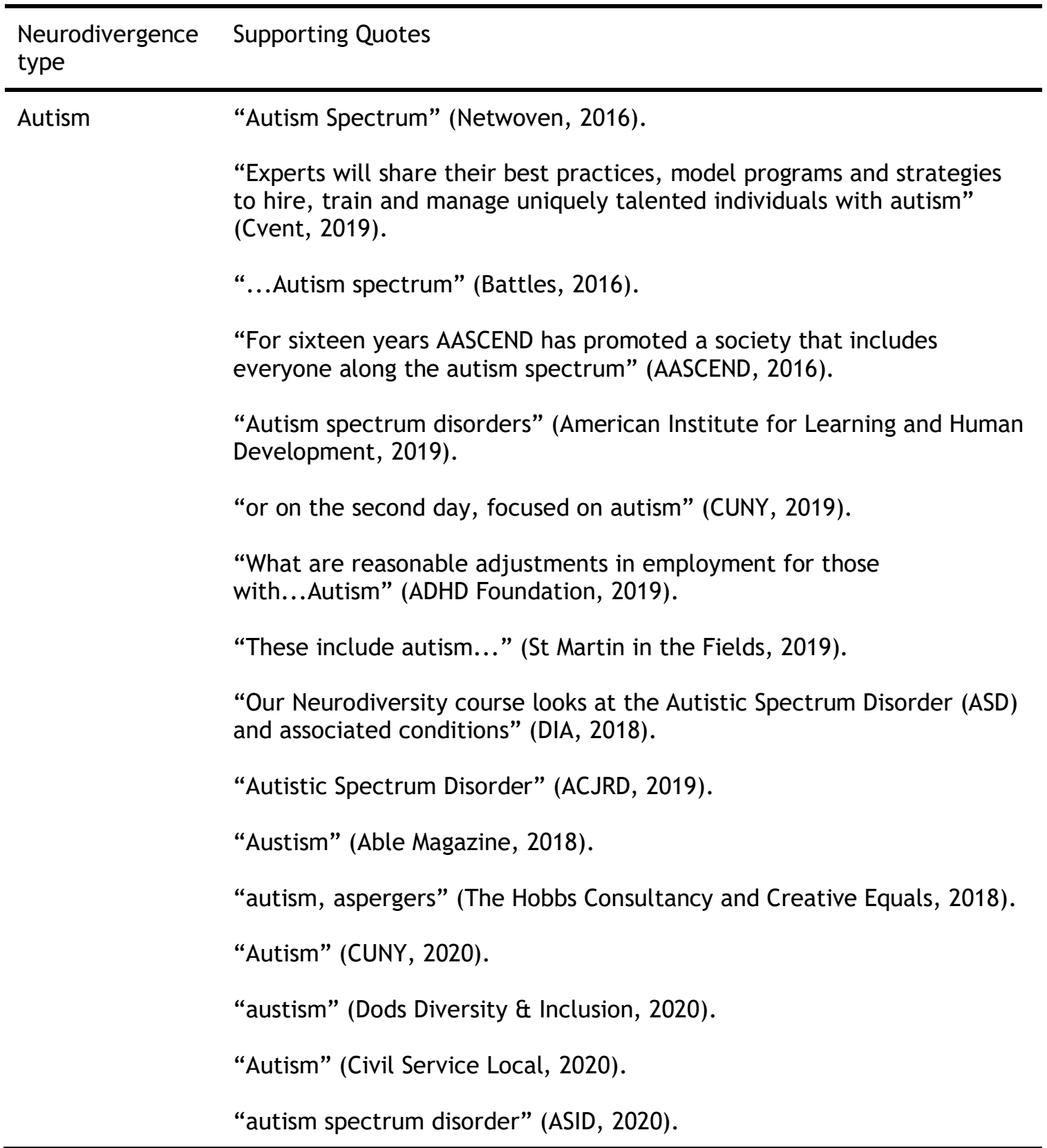

The International Journal of Information, Diversity, \& Inclusion, 5(2), 2021

ISSN 2574-3430, jps.library.utoronto.ca/index.php/ijidi/index

DOI: $10.33137 /$ ijidi.v5i2.35067 


\begin{tabular}{|c|c|}
\hline ADHD & $\begin{array}{l}\text { “..Attention Deficit Hyperactivity Disorder” (Battles, 2016). } \\
\text { “ADHD is a family affair - how ADHD impacts on the family” (ADHD } \\
\text { Foundation, 2019). } \\
\text { “A conference for... adults with ADHD” (YADDA, 2017). } \\
\text { “These include... ADHD” (St Martin in the Fields, 2019). } \\
\text { “ADHD” (ACJRD, 2019). } \\
\text { “ADHD” (Able Magazine, 2018). } \\
\text { “ADHD” (The Hobbs Consultancy and Creative Equals, 2018). } \\
\text { “ADD” (Netwoven, 2016). } \\
\text { “ADHD” (Dods Diversity \& Inclusion, 2020). } \\
\text { “AHDH” (Civil Service Local, 2020). } \\
\text { “attention deficit hyperactivity disorder” (ASID, 2020). }\end{array}$ \\
\hline Dyspraxia & $\begin{array}{l}\text { “These differences include those ‘labelled’ with Dyspraxia” (Battles, } \\
\text { 2016). } \\
\text { “What are reasonable adjustments in employment for those } \\
\text { with...Dyspraxia” (ADHD Foundation, 2019). } \\
\text { “A conference for....adults with Dyspraxia” (YADDA, 2017). } \\
\text { “These include... dyspraxia” (St Martin in the Fields, 2019). } \\
\text { “Dyspraxia” (Able Magazine, 2018). } \\
\text { “dyspraxia” (The Hobbs Consultancy and Creative Equals, 2018). } \\
\text { “dyspraxia” (Dods Diversity \& Inclusion, 2020). } \\
\text { “Dyspraxia” (Civil Service Local, 2020). }\end{array}$ \\
\hline Dyscalculia & $\begin{array}{l}\text { "What are reasonable adjustments in employment for those with... } \\
\text { Dyscalculia" (ADHD Foundation, 2019). } \\
\text { "A conference for... adults with Dyscalculia" (YADDA, 2017) }\end{array}$ \\
\hline Dyslexia & “....dyslexia” (Battles, 2016). \\
\hline
\end{tabular}

The International Journal of Information, Diversity, \& Inclusion, 5(2), 2021 ISSN 2574-3430, jps.library.utoronto.ca/index.php/ijidi/index DOI: $\underline{10.33137 / i j i d i . v 5 i 2.35067}$ 
"What are reasonable adjustments in employment for those with...Dyslexia" (ADHD Foundation, 2019).

“A conference for...adults with Dyslexia” (YADDA, 2017).

“Dyslexia” (Able Magazine, 2018).

“Dyslexia” (Netwoven, 2016).

“dyslexia” (Dods Diversity \& Inclusion, 2020).

“dyslexia” (Civil Service Local, 2020).

“dyslexia” (ASID, 2020).

Tourette “...Tourette Syndrome” (Battles, 2016).

Syndrome

“These include... and Tourette's" (St Martin in the Fields, 2019).

Learning
disability
“Neurodiverse Gifts of Students with Learning Disabilities" (LDAH, 2014).
Morgan Foundation, 2020).

Specific “A conference for... adults with SLI” (YADDA, 2017).

Language

Impairment

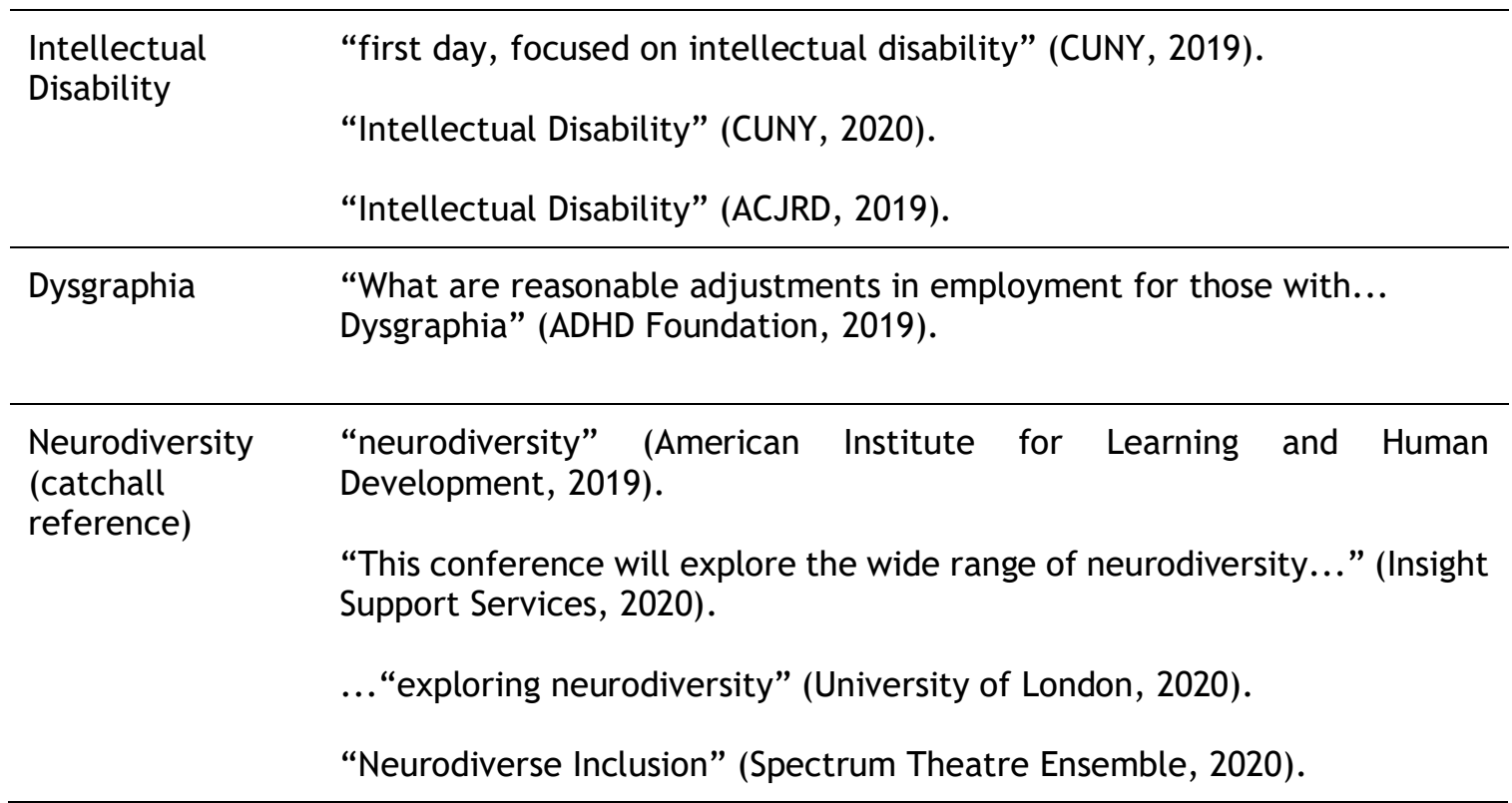

The International Journal of Information, Diversity, \& Inclusion, 5(2), 2021

ISSN 2574-3430, jps.library.utoronto.ca/index.php/ijidi/index

DOI: $\underline{10.33137 / \text { ijidi.v5i2.35067 }}$ 


\begin{tabular}{l}
\hline Others $\quad$ “...and other neurological differences (Cvent, 2019). \\
“...and others” (Battles, 2016). \\
“...and more” (The Hobbs Consultancy and Creative Equals, 2018). \\
“medical conditions” (Netwoven, 2016). \\
"one of a collection of conditions...” (ASID, 2020).
\end{tabular}

Table 4. Conference flyers' proportional representations by neurodivergence type

\begin{tabular}{ll}
\hline Neurodivergence type & \% of conference flyers \\
\hline Autism & 72.3 \\
ADHD & 50.0 \\
Dyslexia & 36.4 \\
Dyspraxia & 36.4 \\
Others (catchall reference \#2) & 22.7 \\
Neurodiversity (catchall reference \#1) & 18.2 \\
Intellectual disability & 13.6 \\
Dyscalculia & 9.1 \\
Tourette syndrome & 9.1 \\
Learning disability & 9.1 \\
SLI & 4.5 \\
Dysgraphia & 4.5 \\
\hline
\end{tabular}

Table 5. Evidence-based themes supporting the explicit inclusion of OCD in neurodiversity conferences

\begin{tabular}{lll}
\hline Theme & Coding Rule & Exemplary Quotes \\
\hline $\begin{array}{l}\text { Intersectionality } \\
\text { (with autism) }\end{array}$ & $\begin{array}{l}\text { Evidence describes } \\
\text { capacity for OCD and } \\
\text { autism intersectionality. }\end{array}$ & $\begin{array}{l}\text { “Co-occurring psychiatric conditions are more } \\
\text { common in ASD than other developmental } \\
\text { disabilities. For example, Croen et al. [6] } \\
\text { found that 54\% of adults with ASD also had }\end{array}$ \\
\hline
\end{tabular}

The International Journal of Information, Diversity, \& Inclusion, 5(2), 2021

ISSN 2574-3430, jps.library.utoronto.ca/index.php/ijidi/index

DOI: $10.33137 /$ ijidi.v5i2.35067 
a psychiatric condition, including as follows: anxiety (29\%), depression (26\%), bipolar disorder (11\%), attention-deficit/hyperactivity disorder (11\%), obsessive-compulsive disorder (8\%), and schizophrenia (8\%)" (Bennett et al., 2018, p. 103).

"Phenotypically, autism frequently co-occurs with other neurodevelopmental (e.g., ADHD, tic disorders) and psychiatric (e.g., anxiety, depression, obsessive-compulsive disorder, psychotic disorders) conditions" (Lai et al. 2014 cited in Lombardo et al. 2019, p. 18).

"The report of the psychiatrists diagnosed it as 'a paranoid form of schizophrenia in which autistiform characteristics are unusually prominent and... an obsessive compulsive personality disorder'" (Lollini, 2018, p. 122).

"autism was also represented as intersecting with other forms of difference such as dual diagnoses (autism and obsessive compulsive disorder or being nonverbal)" (Black et al., 2019, p. 43).

"Types of comorbidities were generally comparable across the ASC and MDD groups, obsessive-compulsive disorder being the only comorbidity that differed significantly between groups" (Lipinski et al. 2019, p. 1156).

"Obsessive-compulsive disorders were also reported although it appeared very difficult to distinguish between these and the ritualistic and stereotyped behaviors of autism (Szatmari et al. 1989)" (Chamak \& Bonniau, 2016, p. 1093).

"Depression, anxiety and obsessive compulsive disorder are reported to be particularly common in younger adults with ASD.14,15" (Foley \& Troller, 2015, p. 785).

"Such reports are corroborated by the observation that around a quarter of adults

The International Journal of Information, Diversity, \& Inclusion, 5(2), 2021 


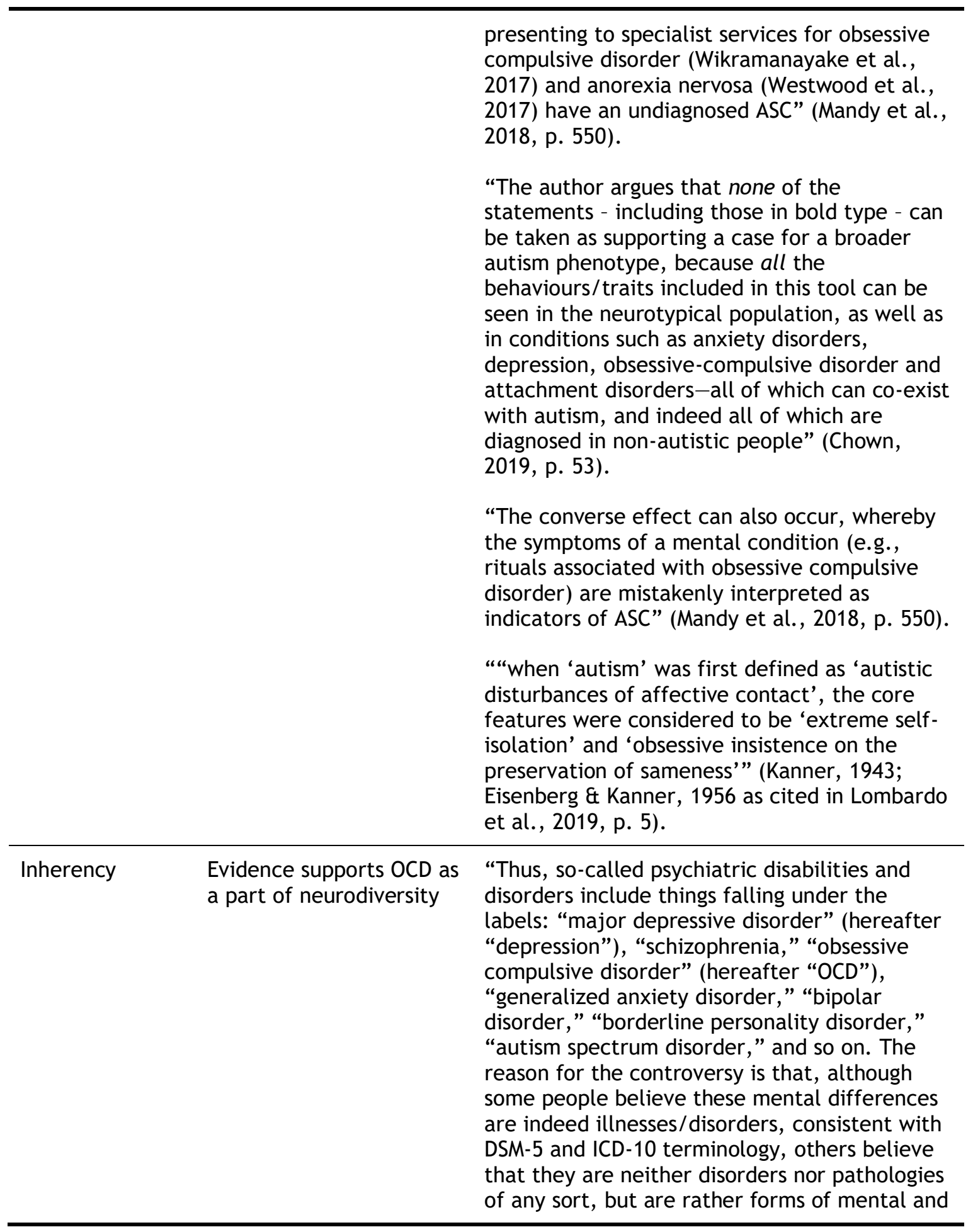

The International Journal of Information, Diversity, \& Inclusion, 5(2), 2021

ISSN 2574-3430, jps.library.utoronto.ca/index.php/ijidi/index

DOI: $\underline{10.33137 / \text { ijidi.v5i2.35067 }}$ 
neural diversity to be accepted and celebrated" (Hoffman \& Hansen, 2017, p. 296).

"Some people with brain differences may or may not choose to identify as neurodiverse, so this categorization is an individual choice not a diagnosis. 3.0 Neurodiverse Conditions other than Autism 3.1 AttentionDeficit/Hyperactivity Disorder (ADHD) 3.2 Learning Disabilities 3.3 Tourette Syndrome 3.4 Obsessive Compulsive Disorder (OCD) 3.5 Other conditions due to neurological differences" (Zolyomi \& Tennis, 2017, p. 139).

"Narrative reported conditions were constrained to neurodiversity (obsessivecompulsive disorder)" (Mellifont et al., 2019, p.1196).

The Google Scholar search delivered 170 possibly relevant articles. After employing the inclusion criteria, 14 articles were considered to be relevant. Table 5 reports on thematic analysis produced themes of comorbidity and inherency, their coding rules, and exemplary quotes.

\section{Discussion}

\section{Neurodiversity conference flyer themes}

This research reveals themes supporting greater inclusion and valuing of neurodivergent persons. Collectively, these themes cover issue-areas of employment, education, social, advocacy, health, and policy. Commencing with employment, this theme was prominent among conference flyers, appearing in well over half (i.e., 63.6\%) of those examined in this exploratory study. The theme was reflected across innovative programs, neurodivergence-related work attributes, and workplace accommodations. Prospective conference attendees were invited to learn about how Fortune 500 companies and others are connecting with community, higher education, and state stakeholders to create hiring programs that are more inclusive (Cvent, 2019). Attendees were encouraged to be informed about an autism-specific employment program (i.e., the Autism Job Club) and Linkedln as a tool for supporting employment (AASCEND, 2016). Delegates of a conference held in England were also given opportunities to be put in touch with "high-profile employers" with examples including Roche and Ford (Able Magazine, 2018). In addition to promoting these kinds of employment programs, measures, and networking opportunities, conferences from the U.S. and England also promoted the potential benefits (e.g., "competitive advantages," "strengths and abilities") of hiring neurodivergent persons (Dods Diversity \& Inclusion, 2020; Adam Morgan Foundation, 2020).

The U.S. based Neurodiversity in the Workplace National Conference spoke about hiring programs that are delivering "business results" (Cvent, 2019). The creativity, innovation, and profitability

The International Journal of Information, Diversity, \& Inclusion, 5(2), 2021

ISSN 2574-3430, jps.library.utoronto.ca/index.php/ijidi/index

DOI: $10.33137 /$ ijidi.v5i2.35067 
offered by diverse minds were also explored and promoted (University of London, 2020; The Hobbs Consultancy and Creative Equals, 2018). Further, conference flyers addressed the strategic policy area of job retention. The Supporting Neurodiversity conference covered the topic of "finding workplace support" (YADDA, 2017). Conferences hosted in the U.S. and England included topics of inclusiveness, "diagnosis and disclosure," as well as reasonable accommodations in the workplace for different types of neurodivergence (ASSCEND, 2016; ADHD Foundation, 2019; Civil Service Local, 2020; ASID, 2020; CUNY, 2020). Accommodating persons with OCD, however, was not included as part of these important conference discussions.

Also prominent among neurodiversity conference flyers was the theme of education $(45.5 \%)$ (see Table 2). Prospective conference attendees were provided with opportunities to learn about the issues that can be experienced by some neurodivergent students. These challenges within "mainstream education" include a prevalence of "social abuse" (Battles, 2016). Academic success in schools was acknowledged and understanding promoted about "processing differences" in this environment by conferences in Canada and the U.S. (LDAH, 2014; Adam Morgan Foundation, 2020). Conferences also raised topics of transitioning to and from university, mental health, and learning supports in higher education, as well as "life-long learning" (The City of New York, 2019; ADHD Foundation, 2019; YADDA, 2017). Moving beyond education in school and university settings, the "Neurodiversity: How prepared are you to train students with hidden disabilities" conference advised driving instructors to expect contact with many neurodivergent students who will want lessons (DIA, 2018). Delegates from a conference that was hosted in Ireland were also informed about how to work with neurodivergent persons in the criminal justice system (ACJRD, 2019). Events that cover topics concerning neurodiversity and the law need to take care that they do not inadvertently promote harmful stereotypes.

Over one-quarter $(27.3 \%)$ of neurodiversity conference flyers spoke about social challenges. These issues were raised at micro and macro levels. At the micro level, flyers discussed personal issues including those of independent living and recreation, dating, and the family impacts of ADHD (The City University of New York, 2019; AASCEND, 2016; ADHD Foundation, 2019). At the macro level, flyers spoke to matters of parental support groups and guardianship options as well as full and genuine social participation (American Institute for Learning and Human Development, 2019; ADHD Foundation, 2019; Spectrum Theatre Ensemble, 2020; Adam Morgan Foundation, 2020). In the wake of COVID-19, some of the neurodiversity conferences informing this study were held in virtual (i.e., online, streamed) settings (e.g., Dods Diversity \& Inclusion, 2020; ASID, 2020; Spectrum Theatre Ensemble, 2020). Research is needed to examine the possible increase in inclusiveness that virtual conferences might offer to some neurodivergent individuals who may find physical attendance at conferences to be socially challenging and anxiety producing.

Appearing in $13.6 \%$ of conference texts was the theme of advocacy. The 2016 Neurodiversity Leaders Conference in San Francisco examined the state of play for autism advocacy (AASCEND, 2016). The Empowering Neurodiversity conference raised the prospect of empowering persons who are "wired differently" to the current rule makers (Battles, 2016). At the same time, conferences need to avoid an ableist assumption that all present rule makers are necessarily neurotypical. Neurodiversity conferences also promoted the sharing of experiences of discrimination (St. Martin in the fields, 2019). In helping to redress these experiences, future studies could examine whether advocacy, when presented as a neurodiversity conference theme, successfully promotes future political collaborations and actions among attendees.

The least proportionally represented themes among neurodiversity conference flyers were those

The International Journal of Information, Diversity, \& Inclusion, 5(2), 2021

ISSN 2574-3430, jps.library.utoronto.ca/index.php/ijidi/index

DOI: $10.33137 /$ ijidi.v5i2.35067 
of health and policy, with each at only 9.1\%. The St Louis Neurodiversity Conference included autism-health sessions about nutrition, the benefits of CrossFit, and "animal therapy" (American Institute for Learning and Human Development, 2019). The 2019 National Neurodiversity and Mental Health conference also described opportunities for ADHD screening at schools (ADHD Foundation, 2019). The medical model of disability positions neurodivergence as something that needs to be identified and fixed (i.e., treated). An unqualified promotion of screening programs at schools, risks adding to stigma by suggesting that neurodivergence is necessarily a medical problem that must be identified as opposed to something that is naturally occurring. This example, however, highlights that care should be taken in conferences with a mental health focus to not stigmatise neurodivergence as something that is necessarily broken (i.e., something that must be exposed, noted, and repaired).

Neurodiversity conferences that were held in England delivered policy-focused topics. Such examples informed participants about a national autism strategy, together with bridging policy directions across national and local platforms (ADHD Foundation, 2019; YADDA, 2017). As policy efforts are fundamental to identifying and redressing the issues that can accompany lived experience with neurodivergence, other countries would do well to follow this strategic direction.

\section{Types of neurodivergence represented in conference flyers}

Autism has received by far the greatest exposure in the neurodiversity conference flyers, appearing in almost three-quarters (72.3\%) of those examined by this study. ADHD was prominent, being identified in half $(50.0 \%)$ of the flyers. Dyslexia and Dyspraxia were also prevalent, each being identified in just over one-third of these promotional texts. Less conspicuous were representations of Intellectual Disability (13.6\%). Also less noted were references to Specific Language Impairment, Learning disability, Dyscalculia, Dysgraphia, and Tourette syndrome.

Explicit references to OCD were not revealed among any of the flyers that were examined. Flyers did, however, apply two catchall phrases in attempts to cover the various kinds of neurodivergence. These terms were "others" and "neurodiversity" (as found in almost one quarter and just less than one-fifth of the flyers respectively). The author recognises the impracticality of including every form of neurodivergence in every neurodiversity conference. Nonetheless, a consistent lack of explicit inclusion of OCD among conferences can be harmful to persons who identify with this particular type of neurodivergence. This inclusivity gap means that opportunities are lost to develop ideas and to inform conference attendees about the practical ways in which to improve the lives of persons with OCD. Attention that is specific to this particular form of neurodivergence is needed to help to: a) redress the discrimination that can be experienced by these individuals; $b$ ) improve the recruitment and retainment of persons with OCD in the workforce; and c) advance the genuine social participation of these persons. The needs and rights of people with OCD might therefore be better supported by recognising the conference inclusion shortfalls as revealed by this investigative study. Such recognition might then act as a starting point for the future growth of neurodiversity conferences.

At a national conference level, countries varied markedly in regards to their referencing of neurodivergence. The flyer for the American Neurodiversity in the Workplace National Conference focused on autism, whereas the England based 2019 National Neurodiversity and Mental Health conference explicitly referred to ADHD, Dyspraxia, Autism, Dyslexia, and

The International Journal of Information, Diversity, \& Inclusion, 5(2), 2021

ISSN 2574-3430, jps.library.utoronto.ca/index.php/ijidi/index

DOI: $10.33137 /$ ijidi.v5i2.35067 
Dyscalculia (Cvent, 2019; ADHD Foundation, 2019). This latter example can be considered better practice in the sense that a spotlight was placed on several forms of neurodivergence within the conference promotional material.

\section{Evidence-based justifications for more "OCD inclusive" neurodiversity conferences}

It is timely to examine the possible extent to which scholarly articles might offer support for the explicit inclusion of OCD in neurodiversity conference materials. The scholarly literature offers two key justifications for a greater inclusion of OCD within neurodiversity conference promotional texts. The first of these is intersectionality. In this regard, autism commonly "cooccurs" with psychiatric disorders including that of OCD (Lai et al., 2014 as cited in Lombardo et al., 2019). Anxiety, depression, and OCD are reported as especially familiar among young adults with ASD (Lugnegård et al., 2011; Matson \& Williams, 2014 as cited in Foley \& Trollor, 2015). Approximately 25 percent of adults who access services for OCD and anorexia nervosa also possess an undiagnosed autism spectrum condition (Wikramanayake et al., 2018; Westwood et al., 2017 as cited in Mandy et al., 2018, p.550). Furthermore, autism-OCD intersectionality is reported in the accounts of study subjects as follows, "she was the first person off of AFF that I have told about my AS, my OCD [Obsessive Compulsive Disorder], my depression, or my schizophrenia" (Parsloe, 2017, p.111). Traits and behaviours witnessed in OCD can co-exist in autism (Chown, 2019).

References to "comorbidity" have been critiqued because in many cases it remains unclear as to whether a diagnosis is truly reflective of distinctive medical conditions or actually reflects various manifestations of a single condition (Maj, 2005). Indeed, it can be challenging to differentiate between OCD and autism's ritualistic behaviours (Szatmari et al., 1989 as cited in Chamak \& Bonniau, 2016). Serious clinical issues can ensue as conditions remain unrecognised or alternately are misdiagnosed with other conditions (Asp et al., 2020; Fusar-Poli et al., 2020).

The blurring of autism and OCD is further reinforced via popular media texts. For example, Harry Potter stories depict autism as overlapping with other appearances of difference including that of OCD (Black et al., 2019). Recognising the potential for autism and OCD intersectionality, Mandy et al. (2018) nevertheless caution that OCD rituals can be incorrectly construed as signs of autism spectrum conditions. Neurodiversity conference materials are thus challenged to explicitly recognise that some persons might have autism and OCD while also depicting, respecting, and including both as distinctive types of neurodivergence.

$O C D$ is inherently recognised as a type of neurodivergence. Specifically, neurodiversity is said to include a range of neurocognitive variances of which OCD is considered to be a part thereof (Hughes, 2016 as cited in Mellifont, 2019). Recognising OCD as falling within the scope of the neurodiversity definition is important. On its own, however, this recognition is not sufficient to justify a greater inclusion of OCD focused content in neurodiversity conferences. Stronger justification is found in the previously described opportunities to tackle ableism (i.e., redress the discrimination that can be targeted at persons with OCD), accommodate OCD where needed, and generally help to improve the lives of many of these individuals.

Hoffman and Hansen (2017) note there are some persons who believe that like autism, OCD is a disorder, and yet there are others who will see these as examples of neurodivergence. Nevertheless, this study recognises possibilities for the social and medical models to co-exist. The prospect is raised that some persons, while realising the strengths (i.e., attributes) that can

The International Journal of Information, Diversity, \& Inclusion, 5(2), 2021

ISSN 2574-3430, jps.library.utoronto.ca/index.php/ijidi/index

DOI: $10.33137 /$ ijidi.v5i2.35067 
accompany their neurodivergence, might also acknowledge their medical diagnosis and the associated challenges that may require accommodations. Moving forward, neurodiversity conferences are challenged to better reflect such nuances in terms of the types of neurodivergence that are explicitly included, their prospective attributes (i.e., abilities), as well as possible challenges and support measures (i.e., accommodations).

\section{Limitations}

This study is restricted to the searches and the data sources selected. These identified neurodiversity conferences were held in the northern hemisphere, with the vast majority of them taking place in either England or the U.S. Future research could undertake searches which include articles that are published in languages other than English. These studies would identify conferences taking place in locations outside of those mentioned in this article. Future studies might also reveal new conference-related themes. Hence, contributions of this qualitative investigation, while valuable, should nonetheless be treated as introductory. Noting that virtual (i.e., online) conferences were included among the sample of neurodiversity conferences, the author also recognises that this sample was likely constricted in volume due to some conference cancellations following COVID-19.

\section{Conclusion}

This exploratory study reveals that neurodiversity conferences cover diverse topics that are central to improving the lives of neurodivergent persons. Issue-areas of employment, education, social, advocacy, health, and policy are each receiving attention. However, such attention is far from evenly distributed. Additionally, this study warns that the policymaking practice that is needed in addressing ableism is currently receiving insufficient attention within neurodiversity conference materials. The study also highlights the consistent failings of conferences to explicitly reference and value $O C D$ as a form of neurodivergence. To be clear, the author is not suggesting that OCD, or any other form of neurodivergence, must necessarily be accounted for in all conferences that are advertised under the neurodiversity banner. What is proposed is that these conferences should reflect diversity to their fullest possible extent. Utilising OCD as an example, this scholarly investigation offers a sound base from which future research can develop. These studies might include searches conducted in languages other than English. They could also focus on differing types of neurodivergence, event formats (e.g., symposiums), and other issues involving conference inclusiveness and intersectionality. It is therefore important that neurodiversity conference organisers remain open to evidence-based ways in which to increase the inclusiveness of their events.

\section{References}

AASCEND. (2016). Neurodiversity leaders 2016 in San Francisco. Retrieved May 10, 2020, from https://sanfrancisco.eventful.com/events/neurodiversity-leaders-2016-/E0-001$\underline{095573747-0}$

Able Magazine. (2018). The Neurodiversity Employment Conference. https: / /ablemagazine.co.uk/neurodiversity-employment-conference/

The International Journal of Information, Diversity, \& Inclusion, 5(2), 2021

ISSN 2574-3430, jps.library.utoronto.ca/index.php/ijidi/index

DOI: $10.33137 /$ ijidi.v5i2.35067 
Adam Morgan Foundation. (2020). 2021 AMF Power of Neurodiversity Conference cultivating success in the classroom \& beyond!

https://adamorgan.networkforgood.com/events/17489-2020-amf-power-ofneurodiversity-conference-cultivating-success-in-the-classroom-beyond

ADHD Foundation. (2019). 2019 National neurodiversity and mental health conference. https: / / www.adhdfoundation.org.uk/wp-content/uploads/2019/05/Conference-2019Leaflet-Multidisciplinary.pdf

Alvares, G. A., Bebbington, K., Cleary, D., Evans, K., Glasson, E. J., Maybery, M. T., Pillar, s., Uljarević, M., Varcin, K., Wray, J. \& Whitehouse, A. J. (2020). The misnomer of 'high functioning autism': Intelligence is an imprecise predictor of functional abilities at diagnosis. Autism, 24(1), 221-232. https://www.doi.org/ 10.1177/1362361319852831

American Institute for Learning and Human Development. (2019). St. Louis Neurodiversity Conference. https: / / www. institute4learning.com/2019/04/05/thomas-armstrong-tospeak-at-st-louis-neurodiversity-conference/

American Society of Interior Designers (ASID). (2020). Neurodiversity and workplace inclusivity. https: / /learn.asid.org/products/neurodiversity-and-workplace-inclusivity-virtualconference-ceu-program

Anxiety and Depression Association of America. (2020). Facts \& statistics. https: / /adaa.org/about-adaa/press-room/facts-statistics\#: :text=0CD\%20affects\% 202.2\% 20million\%20adults, first\%20experienced\%20symptoms\%20in\%20childhood

Arnold, L. (2017). A brief history of "Neurodiversity" as a concept and perhaps a movement. Autonomy, the Critical Journal of Interdisciplinary Autism Studies, 1(5). http://www.larry-arnold.net/Autonomy/index.php/autonomy/article/view/AR23

Asp, M., Lindqvist, D., Fernström, J., Ambrus, L., Tuninger, E., Reis, M., \& Westrin, Å. (2020). Recognition of personality disorder and anxiety disorder comorbidity in patients treated for depression in secondary psychiatric care. PLoS one, 15(1). https: / / doi.org/10.1371/ journal.pone.0227364

Association for Criminal Justice Research and Development (ACJRD). (2019). Neurodiversity and the criminal justice system. Retrieved December 31, 2020, from https://www.acjrd.ie/contents/402

Baron-Cohen, S. (2017). Editorial perspective: Neurodiversity-a revolutionary concept for autism and psychiatry. Journal of Child Psychology and Psychiatry, 58(6), 744-747. https://doi.org/10.1111/jcpp.12703

Battles, L. (2016). Empowering neurodiversity-Developing services for neurodiverse young people with neurodiverse young people [Conference abstract]. ConferenceSeries.com. https://dx.doi.org/10.4172/2165-7890.C1.003

Bennett, A. E., Miller, J. S., Stollon, N., Prasad, R., \& Blum, N. J. (2018). Autism spectrum disorder and transition-aged youth. Current Psychiatry Reports, 20(11), 103. https://www.doi.org/10.1007/s11920-018-0967-y

The International Journal of Information, Diversity, \& Inclusion, 5(2), 2021

ISSN 2574-3430, jps.library.utoronto.ca/index.php/ijidi/index

DOI: $10.33137 /$ ijidi.v5i2.35067 
Berridge, C. W., \& Martinson, M. (2018). Valuing old age without leveraging ableism. Generations, 41(4), 83-91. https: //depts.washington.edu/uwmedptn/wpcontent/uploads/Valuing-Old-Age-Without-Leveraging-Ableism-Feb-2019.pdf

Black, R., Alexander, J., Chen, V., \& Duarte, J. (2019). Representations of autism in online Harry Potter fanfiction. Journal of Literacy Research, 51(1), 30-51. https://doi.org/10.1177/1086296X18820659

Braun, V., \& Clarke, V. (2006). Using thematic analysis in psychology. Qualitative Research in Psychology, 3(2), 77-101. https://doi.org/10.1191/1478088706qp063oa

Callus, A. M. (2017). Making disability conferences more actively inclusive. Disability \& Society. 32(10), 1661-1665. https://doi.org/10.1080/09687599.2017.1356059

Chamak, B., \& Bonniau, B. (2016). Trajectories, long-term outcomes and family experiences of 76 adults with autism spectrum disorder. Journal of Autism and Developmental Disorders, 46(3), 1084-1095. https://www.doi.org/10.1007/s10803-015-2656-6

Chapman, R. (2020). Defining neurodiversity for research and practice. Neurodiversity Studies: A New Critical Paradigm, 14. https: / /www.doi.org/10.4324/9780429322297-21

Chapman, R. (2021, February 13). Neurodiversity and the ecology of thought. Psychology Today. https: / / www.psychologytoday.com/us/blog/neurodiverseage/202102/neurodiversity-and-the-ecology-thought

Chown, N. (2019). Are the "autistic traits" and "broader autism phenotype" concepts real or mythical. Autism Policy and Practice, 2(1), 46-63. https://www.openaccessautism.org/index.php/app/article/view/19/38

Civil Service Local. (2020). Neurodiversity - It takes all kinds of different minds. Retrieved January 1, 2021, from https: //web.archive.org/web/20201129170832/https: //civilservicelocal.blog.gov.uk/2 $\underline{020 / 10 / 27 / c s-l o c a l-a r e-c e l e b r a t i n g-n e u r o d i v e r s i t y / ~}$

Clare, E. (2004). An end to ableism in higher education. https: //eliclare.com/what-elioffers/lectures/ableism

Clouder, L., Karakus, M., Cinotti, A., Ferreyra, M.V., Fierros, G.A. and Rojo, P. (2020). Neurodiversity in higher education: a narrative synthesis. Higher Education 80, 757778. https: //www.doi.org/10.1007/s10734-020-00513-6

Coe, I. R., Wiley, R., \& Bekker, L. G. (2019). Organisational best practices towards gender equality in science and medicine. The Lancet, 393(10171), 587-593. https: //www.doi.org/10.1016/S0140-6736(18)33188-X

Cvent. (2019). Neurodiversity in the workplace national conference: $A$ collaborative conference event. Retrieved November 26, 2019, from https: / / www.cvent.com/events/neurodiversity-in-the-workplace-nationalconference/event-summary-b2f41912714a4101aa67c6f107806e99.aspx 
Dalton, N. (2013). Neurodiversity $\mathrm{HCl}$. Interactions, 20(2), 72-75. https: / /interactions.acm.org/archive/view/march-april-2013/neurodiversity-hci

den Houting, J. (2019). Neurodiversity: An insider's perspective. Autism 23(2), 271-273. https://www.doi.org/10.1177/1362361318820762

De Picker, M. (2019). Rethinking inclusion and disability activism at academic conferences: Strategies proposed by a PhD student with a physical disability. Disability \& Society 35(1), 163-167. https://doi.org/10.1080/09687599.2019.1619234

Dods Diversity \& Inclusion. (2020). Neurodiversity at work: Thinking differently \& supporting unique talents. https: / / www. dodsdiversity.com/upcoming-events/view, neurodiversityat-work-thinking-differently-supporting-unique-talents_160.htm

Doyle, N. (2020). Neurodiversity at work: A biopsychosocial model and the impact on working adults. British Medical Bulletin, 135(1), 108-125.

https://doi.org/10.1093/bmb/ldaa021

Driving Instructor Academy (DIA). (2018). Neurodiversity: How prepared are you to train students with hidden disabilities. https: / /emilywooddesign.files. wordpress.com/2018/12/Neurodiversity-Flyer.pdf

Dyck, E., \& Russell, G. (2020). Challenging psychiatric classification: Healthy Autistic diversity the neurodiversity movement. In S. Taylor \& A. Brumby (Eds.), Healthy minds in the twentieth century (pp. 167-187). Palgrave Macmillan. https://doi.org/10.1007/978-3030-27275-3_8

Eisenberg, L., \& Kanner, L. (1956). Childhood schizophrenia: Symposium, 1955: 6. Early infantile autism, 1943-55. American Journal of Orthopsychiatry, 26(3), 556. https://doi.org/10.1111/j.1939-0025.1956.tb06202.x

Ferman, T. (2002). Academic professional development practice: What lecturers find valuable. The International Journal for Academic Development, 7(2), 146-158. https://doi.org/10.1080/1360144032000071305

Foley, K. R., \& Trollor, J. (2015). Management of mental ill health in people with autism spectrum disorder. Australian Journal of General Practice, 44(11), 784. https: //pubmed.ncbi.nlm.nih.gov/26590616/

Fusar-Poli, L., Brondino, N., Politi, P., \& Aguglia, E. (2020). Missed diagnoses and misdiagnoses of adults with autism spectrum disorder. European Archives of Psychiatry and Clinical Neuroscience, 1-12. https: / / doi.org/10.1007/s00406-020-01189-w

Gordon, S., \& Gledhill, K. (2018). What makes a 'good' conference from a service user perspective? International Journal of Mental Health and Capacity Law 23(2017), 109128. https://doi.org/10.19164/ijmhcl.v2017i24.686

Hayes-Skelton, S. A, Orsillo S. M., Roemer, L. (2013). An acceptance based behavioral therapy for individuals with generalized anxiety disorder. Cognitive and Behavioral Practice, 20(3), 264-281. https://www.doi.org/10.1016/j.cbpra.2011.02.005 
Hickson, I, M. (2006). Raising the question \# 4 why bother attending conferences?. Communication Education, 55(4), 464-468.

https://doi.org/10.1080/03634520600917632

Hehir, T., (2002). Eliminating ableism in education. Harvard Educational Review, 72(1), 1-33. https://doi.org/10.17763/haer.72.1.03866528702g2105

Hoffman, G. A., \& Hansen, J. L. (2017). Prozac or prosaic diaries?: The gendering of psychiatric disability in depression memoirs. Philosophy, Psychiatry, \& Psychology, 24(4), 285-298. https://www.doi.org/10.1353/ppp.2017.0041

Hughes, J. M. (2016). Increasing neurodiversity in disability and social justice advocacy groups. Autistic Self Advocacy Network. https: / / autisticadvocacy.org/wpcontent/uploads/2016/06/whitepaper-Increasing-Neurodiversity-in-Disability-andSocial-Justice-Advocacy-Groups.pdf

Insight Support Services. (2020). Nurturing invisible superpowers: A conference on neurodiversity. https: / /insightsupportservicesandeducationprogram.ca/neurodiversityconference

International OCD Foundation. (2019). 26th Annual OCD conference. https://iocdf.org/calendar/26th-annual-ocd-conference-austin-tx/

Johnson, A. (2014). Obsessional slowness in college students: Case studies. Journal of College Student Psychotherapy, 28(3), 241-488. https://doi.org/10.1080/87568225.2014.915173

Kanner, L. (1943). Autistic disturbances of affective contact. Nervous Child, 2(3), 217-250.

Kapp, S.K., Gillespie-Lynch, K., Sherman, L.E. and Hutman, T. (2013). Deficit, difference, or both? Autism and neurodiversity. Developmental psychology, 49(1), 59. https://www.doi.org/10.1037/a0028353

Lai, MC., Lombardo, MV., \& Baron-Cohen, S. (2014). Autism. The Lancet, 383(9920), 896-910. https://doi.org/10.1016/S0140-6736(13)61539-1

Learning Disabilities Association of Halon (LDAH). (2014). Solutions for learning conference: Neurodiversity rocks! https: //ldahh.ca/annual-conference/

Lipinski, S., Blanke, E. S., Suenkel, U., \& Dziobek, I. (2019). Outpatient psychotherapy for adults with high-functioning autism spectrum condition: Utilization, treatment satisfaction, and preferred modifications. Journal of Autism and Developmental Disorders, 49(3), 1154-1168. https: / /www.doi.org/10.1007/s10803-018-3797-1

Lollini, A. (2018). Brain equality: Legal implications of neurodiversity in a comparative perspective. New York University Journal of International Law \& Politics, 51(1), 69. https: / / nyujilp.org/wp-content/uploads/2019/01/NYI102.pdf

Lombardo, M. V., Lai, M. C., \& Baron-Cohen, S. (2019). Big data approaches to decomposing heterogeneity across the autism spectrum. Molecular Psychiatry, 24(10), 1435-1450.

The International Journal of Information, Diversity, \& Inclusion, 5(2), 2021

ISSN 2574-3430, jps.library.utoronto.ca/index.php/ijidi/index

DOI: $\underline{10.33137 / i j i d i . v 5 i 2.35067}$ 
https://doi.org/10.1038/s41380-018-0321-0

Lugnegård, T., Hallerbäck, M. U., \& Gillberg, C. (2011). Psychiatric comorbidity in young adults with a clinical diagnosis of Asperger syndrome. Research in Developmental Disabilities, 32(5), 1910-1917. https: / / www.doi.org/10.1016/j.ridd.2011.03.025

Maj, M. (2005). Psychiatric comorbidity: An artefact of current diagnostic systems? The British Journal of Psychiatry, 186(3), 182-184. https://www.doi.org/10.1192/bjp.186.3.182

Mandy, W., Clarke, K., McKenner, M., Strydom, A., Crabtree, J., Lai, M. C., Allison, C., BaronCohen, S., \& Skuse, D. (2018). Assessing autism in adults: An evaluation of the developmental, dimensional and diagnostic interview - Adult version (3Di-Adult). Journal of Autism and Developmental Disorders, 48(2), 549-560. https://www.doi.org/10.1007/s10803-017-3321-z

Manning, J. (2018). Making the most of our conferences and associations: An important component for communication research, teaching, and service. Communication Studies, 69(5), 605-616. https://doi.org/10.1080/10510974.2018.1520734

Mathieson, D. (2009). The London summit: Milestone or stumbling block. Real Instituto Elcano. http://www.realinstitutoelcano.org/wps/wcm/connect/5b603c004f018a379944fd3170b aead1/ARI47-

2009_Mathieson_London_Summit_2009.pdf?MOD=AJPERES\&CACHEID =5b603c004f018a37 9944fd3170baead1

Matson, J. L., \& Williams, L. W. (2014). Depression and mood disorders among persons with autism spectrum disorders. Research in Developmental Disabilities, 35(9), 2003-2007. https://www.doi.org/10.1016/j.ridd.2014.04.020

McWade, B., Milton, D. and Beresford, P. (2015). Mad studies and neurodiversity: A dialogue. Disability \& Society, 30(2), 305-309.

https://doi.org/10.1080/09687599.2014.1000512

Mellifont, D. (2019). Neuro magnifico! An exploratory study critically reviewing news text reporting of anxiety-related work performance strengths, challenges and support measures. Work, 63(3), 435-446. https://doi.org/10.3233/wor-192950

Mellifont, D., Smith-Merry, J., Dickinson, H., Llewellyn, G., Clifton, S., Ragen, J., \& Williamson, P. (2019). The ableism elephant in the academy: A study examining academia as informed by Australian scholars with lived experience. Disability \& Society, 34(7-8), 1180-1199. https://doi.org/10.1080/09687599.2019.1602510

Milton, D., \& Moon, L. (2012). The normalisation agenda and the psycho-emotional disablement of autistic people. Autonomy, the Critical Journal of Interdisciplinary Autism Studies, 1(1). http: //www.larryarnold.net/Autonomy/index.php/autonomy/article/view/9

Murdock, J. (2020). Autism: A function of neurodiversity? Journal of Human Services: Training, Research, and Practice, 5(1), 5. https://scholarworks.sfasu.edu/jhstrp/vol5/iss1/5

The International Journal of Information, Diversity, \& Inclusion, 5(2), 2021

ISSN 2574-3430, jps.library.utoronto.ca/index.php/ijidi/index

DOI: $10.33137 /$ ijidi.v5i2.35067 
Netwoven. (2016). Neurodiversity in the high-tech workforce: Celebrating abilities in a culture of disability. https: //www. netwoven.com/events/neurodiversity-in-the-high-techworkforce-celebrating-abilities-in-a-culture-of-disability/

Ngamsom, B., \& Beck, J. (2000). A pilot study of motivations, inhibitors, and facilitators of association members in attending international conferences. Journal of Convention \& Exhibition Management, 2(2-3), 97-111. https://doi.org/10.1300/J143v02n02_09

Neves, J., Lavis, J. N., \& Ranson, M. K. (2012). A scoping review about conference objectives and evaluative practices: How do we get more out of them? Health Research Policy and Systems, 10(1), 26. https://doi.org/10.1186/1478-4505-10-26

Ortega, F. (2009). The cerebral subject and the challenge of neurodiversity. BioSocieties, 4(4), 425-445. https: / /www.doi.org/10.1017/S1745855209990287

Parsloe, S. M. (2017). Dialogue with a diary and a diarist: Writing/listening as healing. Departures in Critical Qualitative Research, 6(1), 95-118. https://doi.org/10.1525/dcar.2017.6.1.95

Parsons, A.L., Reichl, A.J. \& Pedersen, C.L. (2017). Gendered ableism: media representations and gender role beliefs' effect on perceptions of disability and sexuality. Sexuality and Disability, 35(2). 207-225. https://doi.org/10.1007/s11195-016-9464-6

Rog, S., \& Wolffe, S. (1994). Economic impact study. Convention Liaison Council.

Rothstein, A. (2012). Mental disorder or neurodiversity? The New Atlantis, 99-115. https://www.thenewatlantis.com/publications/mental-disorder-or-neurodiversity

Russell, G. (2020). Critiques of the neurodiversity movement. In S. Kapp (Ed.) Autistic community and the neurodiversity movement (pp. 287-302). Palgrave Macmillan. https: //www.doi.org/10.1007/978-981-13-8437-0_21

Sane Australia. (2018). Obsessive compulsive disorder (OCD). https: / / www.sane.org/information-stories/facts-and-guides/obsessive-compulsivedisorder

Silberman, S. (2017). Neurotribes: The legacy of autism and how to think smarter about people who think differently. Atlantic Books.

Spectrum Theatre Ensemble. (2020). Neurodiversity matters conference. https: //howtround.com/happenings/neurodiversity-matters-conference

St Martin in the Fields. (2019). Thinking differently about God: Neurodiversity, faith \& church. https: //www.inclusivechurch.org/sites/default/files/files/TDAG\%202019\%20leaflet\%20WEB(1).pdf

Storey, K., (2007). Combating ableism in schools. Preventing School Failure: Alternative Education for Children and Youth, 52(1), 56-58. https://doi.org/10.3200/PSFL.52.1.56-58 
Strand, L.R., (2017). Charting relations between intersectionality theory and the neurodiversity paradigm. Disability Studies Quarterly, 37(2). https://dsq-

sds.org/article/view/5374/4647

Szatmari, P., Bartolucci, G., Bremner, R., Bond, S., \& Rich, S. (1989). A follow-up study of high-functioning autistic children. Journal of Autism and Developmental Disorders, 19(2), 213-225. https://doi.org/10.1007/BF02211842

Tepper, S. J., \& Hinton, S. (2003). The measure of meetings: Forums, deliberation, and cultural policy. Working Paper Series: Princeton University.

The City University of New York (CUNY). (2019). 2nd annual CUNY neurodiversity conference. Retrieved November 26, 2019, from https: / / opencuny.org/cunydisabilityscholars/files/2018/10/Call-for-ProposalsNeurodiversity-Conference-2019.pdf

The City University of New York (CUNY). (2020, March 12). 3rd Annual CUNY neurodiversity conference. https://mydiversability.com/calendar/2020/3/12/outing-3rd-annual-cunyneurodiversity-conference

The Hobbs Consultancy and Creative Equals. (2018, March 1). Diverse minds: The neurodiversity conference. https: //www.eventbrite.co.uk/e/diverseminds-theneurodiversity-conference-tickets-39830662584

University of London. (2020, October 20). Online conference: Neurodiversity and the creative arts. http://www.bcmh.bbk.ac.uk/2020/10/20/online-conference-neurodiversity-andthe-creative-arts-16-17-november/

van de Venter, R. (2019). Is there a difference between a congress, conference, symposium, seminar, journal club, and workshop in terms of continuing professional development activities? The South African Radiographer, 57(1), 24-26.

https://www.researchgate.net/publication/333210512_Is_there_a_difference_between _a_congress_conference_symposium_seminar_journal_club_and_workshop_in_terms_of _continuing_professional_development_activities

Westwood, H., Mandy, W., \& Tchanturia, K. (2017). Clinical evaluation of autistic symptoms in women with anorexia nervosa. Molecular Autism, 8(12), 1-9.

https://www.doi.org/10.1186/s13229-017-0128-x

Wikramanayake, W. N. M., Mandy, W., Shahper, S., Kaur, S., Kolli, S., Osman, S., Reid, J., Jefferies-Sewell, K., \& Fineberg, N. A. (2018). Autism spectrum disorders in adult outpatients with obsessive compulsive disorder in the UK. International Journal of Psychiatry in Clinical Practice, 22(1), 54-62. https: / / www.doi.org/10.1080/13651501.2017.1354029

Williams, K. (2019, April 4). The fallacy of functioning labels. NCMH. https: //www.ncmh.info/2019/04/04/fallacy-functioning-labels/

YADDA. (2017). Supporting neurodiversity. Retrieved December 9, 2019, from https: //yadda.org.uk/ Conference\%20flyer\%20final\%20copy.pdf 
Zolyomi, A., \& Tennis, J. T. (2017). The Autism prism: A domain analysis paper examining neurodiversity. NASKO, 6(1), 139-172. http://dx.doi.org/10.7152/nasko.v6i1.15237

Damian Mellifont (damian.mellifont@sydney.edu.au) is an Honorary Postdoctoral Fellow of the Centre for Disability Research and Policy at The University of Sydney, Sydney, Australia. 